\section{B A Institute of \\ YK Business Administration \\ 光 \\ Karachi \\ Leadership and Ideas for Tomorrow}

\section{Business Review}

Volume 7 Issue 1 January-June 2012

$1-1-2012$

\title{
International business environment analysis
}

Sana Khalil

School of Economics and Trade, Hunan University, China

Follow this and additional works at: https://ir.iba.edu.pk/businessreview

Part of the International Business Commons, and the International Economics Commons

(c) (†)

This work is licensed under a Creative Commons Attribution 4.0 International License.

\section{Recommended Citation}

Khalil, S. (2012). International business environment analysis. Business Review, 7(1), 28-42. Retrieved from https://doi.org/10.54784/1990-6587.1299

This article is brought to you by iRepository for open access under the Creative Commons Attribution 4.0 License and is available at https://ir.iba.edu.pk/businessreview/vol7/iss1/3. For more information, please contact irepository@iba.edu.pk. 


\title{
ARTICLE
}

\section{International Business Environment Analysis}

\author{
Sana Khalil \\ School of Economics and Trade, Hunan University, China
}

\begin{abstract}
This paper presents business environment analysis on the basis of cultural and economic differences. It elucidates the potential conflicts, risks and discusses the business opportunities that lie amid this whirlpool. The cultural differences are analyzed using Hofstede's dimensions and subsequent implications are discussed. It elucidates that the socio-economic differences require the managers to use their discretion while developing business strategies or goods and services for different markets. Since BRICS nations are emerging as potential business markets for firms around the globe and have attracted much attention and debate, I have chosen to present a comparative analysis using BRICS countries and USA for developing my case study.
\end{abstract}

\section{Introduction}

The rise of BRICS countries has attracted global attention of businesses and researchers alike. The BRICS nations, as of 2011, contribute one-third of World's population with a combined nominal GDP of US \$ 13.6 trillion. This translates into huge customer base, enormous demand, and market potential for managers around the world. The four BRIC economies, if we exclude South Africa, have a total combined population of 2.7 billion which is slightly less than half the world's total population. The average growth rate for these economies over last five years has been around $10 \%$. The growth forecast for BRICS is at a high level of $9 \%$ showing robustness of their economies (IMF \& World Bank figures).

Given the recent debt crisis and the market saturation in mature economies, the businesses are looking towards the emerging markets for boosting their declining bottom line from home markets. The problems of debt burden and subsequent layoffs coupled with agonies caused by inflation have strained the consumer demand in mature markets. On the other hand, the rapid growth of emerging nations has enabled huge consumption creating enormous market potential for businesses to expand their operations to such countries. In my essay, I have tried to present a comparative analysis of these emerging markets on socio-economic dimensions. In the first part I have depicted the cultural differences using Hofstede's cultural dimension and the resulting implications for businesses. The second and third parts discuss the role of macroeconomic indicators while highlighting the application of Linder theory (on trade behavior of different countries) in these markets.

\section{Scenario analysis}

I am working as the Business Strategy Analyst for a multinational firm ABC in United States of America. The company has its head office and major operations in USA 
but it has expanded its operations to the developed markets of Europe i.e. Germany, France, Canada and United Kingdom. Our operations have been very successful with satisfactory bottom line of our financial statements until the economic crisis took its toll over recent years. The first blow was caused by the financial crisis most appropriately called as "Subprime Mortgage Crisis". Our operations in USA were first to be hit by the crippled sales and operations. Soon after the bankruptcy of financial giants like HSBC (which prided itself as world's largest bank), Lehman Brother the fourth largest investment bank), Goldman Sachs and Citigroup in 2008, our company found itself stranded for acquiring funds for investment (New York Times, 2008).

Not only did it become difficult to raise capital in the local financial markets, but it become almost impossible to look toward financial markets of Europe since the crisis had spread like an epidemic to these countries within few months. The huge layoffs and downsizing measures taken by companies lead to unemployment and thereby devastated the average consumer in an unprecedented manner. As a strategy analyst, I have been closely monitoring the situation during all that period and I found a sharp slump in our sales not only in USA but in all the other four countries too. Our financial statements have shown huge losses from these markets. After the government bailouts and measurements, the situation did stabilize a bit as our losses were reduced to some extent while the consumer demand recovered. As we prepared to recover from the previous crisis, the recent debt crisis in USA tarnished our optimism again. Our forecasts for recovery in consumer demand and sales were met by a heavy blow from the recent developments on the USA debt crisis. As quoted by the Telegraph, December 2011, the situation has turned serious;

"US consumer spending rose less than forecast in November as wages declined for the first time in three months - not good news after yesterday's more encouraging signs of recovery in the world's biggest economy." (The Telegraph, 2011)

It's appropriate to reflect the opinion of economists about the situation and the future picture. Yelena Shulyatyeva, an economist at BNP Paribas in New York, was quoted to tell Bloomberg;

"In the absence of a significant pickup in income, we won't see a big boost in spending. The momentum will slow in the fourth quarter"

The drop in U.S. wages in recent months has restrained overall income of average consumer. To add fuel to fire, the financial statements from UK and other countries are showing a very dismal outlook for our company's future. The European markets are facing huge financial problems and the declining consumer demand (BBC News, 2011).

Europe's economy is appraised to be taking a toll on the U.K too with the news arriving that its high growth industry of services that account for about 75 percent of the economy fell by 0.7 percent in October (The Bloomberg).

Apart from economic woes, my analysis of all five countries, where we are holding business operations, reveals that we are facing market saturation in those countries. We faced little competition during the first few years of our operation thereby reaping huge profits. But, the competition has turned fierce over past few years given the tremendous struggle of companies to attract the subdued consumer demand. We are fighting for survival in these countries with neck to neck competition.

Given the dismal picture above, we can look towards the emerging markets for the viability of our organization. That is, the immense growth in the rapidly expanding economics of BRICS nations and sharp rise in consumer spending invites our attention for expanding our business operations in profitable markets. 
I am preparing this research report to present a complete analysis of our current standing, the business opportunities for us in emerging markets along with recommendations for the strategies for these countries.

\section{Our organization}

$\mathrm{ABC}$ is a multinational company with operations in USA, UK, Germany, France and Canada. As a responsible organization, we are committed to creating value for our customers by providing products and services of consistently excellent quality and standards. Our emphasis on the value creation for customers has enabled us to be one of the top providers of products and services in the regions in which we operate. We have more than 50 years of experience in consumer goods and services with a rich diverse culture and product portfolio.

\section{Our mission statement}

"To provide products and services of superior quality for customers through continuous product differentiation who would reward us with market leadership, sales and overall profitability in the return of value that we create for them".

\section{Organization Structure}

Since our mission statement emphasizes on product differentiation, we currently follow a functional structure that favors implementation of product differentiation strategies. Since product differentiation requires flexibility and room for innovation, our setup is based on informal structure of communication flow. That's, we have implemented two-way communication flow that requires informal knowledge and information sharing among all level of organization. We appreciate horizontal communication flow rather than downward communication flow (from the boss to employees) since our organizational culture is not authoritarian and is rather free.

Figure 1: Organizational structure of our firm

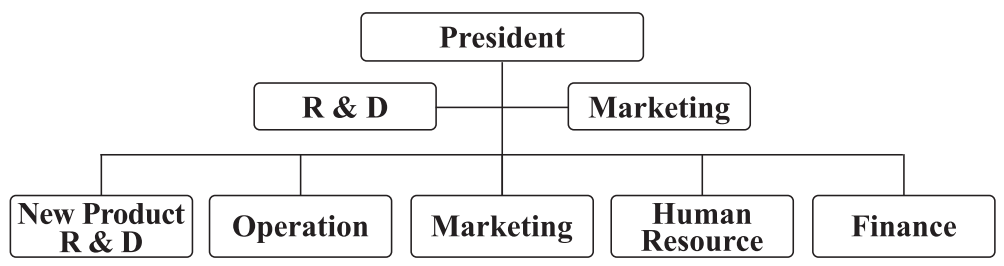

\section{Business Structure}

Figure 2: Our global business units

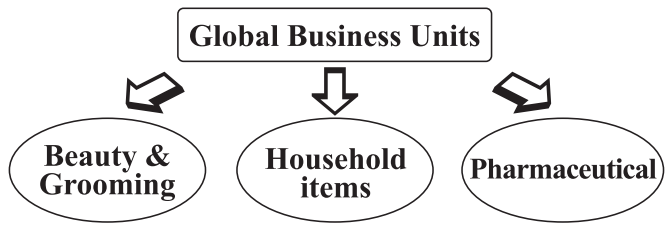




\section{Our Business Strategy}

We follow Multi-domestic strategy in order to achieve maximum local responsiveness by customizing our product offerings and marketing strategies to meet local conditions. Thus our subsidiaries in other countries are able to incorporate the environmental and local aspects of demand at national level.

\section{Business environment analysis}

Given our mission, structure and strategy, I have divided my analysis of emerging countries in two parts; the first part delves into cultural aspects of BRICS nations and the second part discloses economic and trade implications for our business.

\section{Cultural Comparison}

\section{Hostede's cultural dimensions and their implications}

Hofstede's cultural dimensions are used for analysis of cultural beliefs and attitudes in a society. Decisions for expanding business to potential emerging markets need to be made in the light of the cultural differences that the firms can tolerate and manage. While the scores for most of the dimensions were available from the original research work carried out by Geert Hostede, the scores for South Africa and Russia were not given for long-term orientation (LTO). While I succeeded to come up with an arbitrary estimate According to Alexander Ardichvili, there is low degree of LTO for Russia, therefore I came up with a hypothetical estimate of 33 keeping in mind the world average for LTO-42 of LTO for Russia based upon the research work carried out by Alexander ArdichviliAlexander Ardichvili, a specialist in HR Management across regions and the most influential scholar to take Bass' theories and apply them specifically to practices in the former Soviet Union (2001), I couldn't find such estimate for South Africa.

Also, I have included the world averages from Wikia.com for Hofstede's dimensions in the graphical representation to elaborate the extent of cultural differences and their implications for a firm from a mature market such as USA.

The graphical representation of the Hostede's dimensions For detailed scores, please refer to appendix for BRICS and United States along with world averages is given below;

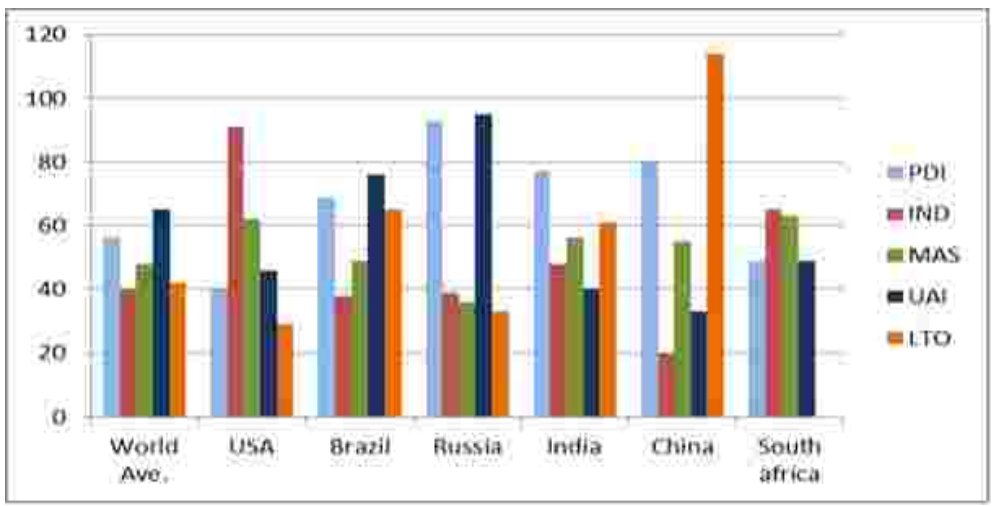

Figure3: Graphical representation of Hofstede's dimensions for BRICS and USA 


\begin{tabular}{|c|l|c|c|}
\hline $\begin{array}{c}\text { Hofstede's } \\
\text { Dimensions }\end{array}$ & \multicolumn{1}{|c|}{ High } & Low & $\begin{array}{c}\text { Medium } \\
\text { or near medium }\end{array}$ \\
\hline PDI & $\begin{array}{l}\text { Russia, China, India, } \\
\text { Brazil }\end{array}$ & U.S.A. & South Africa (49) \\
\hline IND & U.S.A, South Africa & China, Brazil, Russia & India (48) \\
\hline MAS & $\begin{array}{l}\text { South Africa, U.S.A } \\
\text { India, China }\end{array}$ & Russia & Brazil (49) \\
\hline UAI & Russia, Brazil & U.S.A, China, India & South Africa (49) \\
\hline LTO & China, Brazil, India & Russia, U.S.A. & \\
\hline
\end{tabular}

Table 1: Grouping of countriess across Hofstede's dimensions

\section{High PDI}

High degree of PDI shows the acceptance for inequalities by the society. It reflects that the society believes in the hierarchical distribution of power attaching importance to status symbols for power.

Quite interestingly, all the BRICS countries except South Africa are high in PDI showing that the individuals having authority in an organization are highly important, respected and responsible for decision making. Thus, according to the hierarchical position of the individual, there would be strong differentiation in terms of power, status, competence and roles etc.

Russia (93) and China (80) are very high in PDI among other BRICS nations. The huge discrepancy in power requires distinct status roles, a top-down approach and clear mandates for each task in all areas of business interactions. Top management makes the decisions while lower level of management is meant to accept them and carry out the orders. Communication is formal, restricted and centralized.

South Africa (49) lies at the medium border for PDI. This means the people accept hierarchy and centralization to large extent. However, one may expect some exceptions in terms of roles and mandates for tasks in some cases. This requires the discretion and intuition of the business manager to deal different situations differently.

\section{Low PDI}

Low PDI means equality in all aspects of society. United States (40) ranks low on this dimension which reflects that the American society believes in liberty and justice for all. In organizations, hierarchy is meant for convenience and the superiors rely on individual employees and teams for their expertise. Top management is always accessible and can be consulted directly by the employees at medium and lower level. Communication is frequent, direct, informal and open to all.

\section{High IND}

Individual interests are more important than the interests of the group. There is highusage of "I" instead of "we". Individual contributions and tasks are appraised and 
rewarded. Communication is compact and is started directly with business details.

US (91) and South Africa (65) are high in IND, showing individualistic societies. The organizations' relationship with employees is based on mutual advantage while hiring and firing decisions are based on merit only. Individuals are accustomed to meet and interact with strangers and approach counterparts to seek information and help. Employees are selfdependent. Creativity and initiatives are encouraged.

India (48) lies in the middle region. Though the society mostly reflects collectivistic tendency but there may be some exceptions in terms of contributions and perceptions toward group outcome versus individual outcome. It means that one may come across a situation where individuals may reflect self-dependency, freedom of initiatives, and individual contribution.

\section{Low IND}

Low individualism represents collectivistic culture. The interests of the group prevail over individual interests. There is high sense of moral obligation and loyalty toward the group and society. "We" is preferred over "I". The group outcome matters instead of individual contribution.

China (20) is very low in IND which shows that the society is strongly marked by collectivism. Also, Brazil (38) and Russia (39) are ranked low in IND which shows that individual has less autonomy and decisions are deliberated by the group.

The strong aspect for working environment is that the business is made on the basis of trustworthy and long-lasting relations. The business meetings are started with long informal conversations and parties involved get to know each other before reaching on any agreement. The communication style is profuse, context-rich and detailed. Often communication starts with personal details and ends with business details. The relationships are important in business negotiations and winning contracts.

\section{High Masculinity}

High level of this index shows that individual behaviors are marked by competition, achievements and financial gains from school to the workplace.

South Africa (53), US (62), China (55), India (56) are marked by masculine societies. Managers in these countries are expected to be assertive, competitive and decisive. Competition and performance matter a lot. Contracts are won by fighting to be the best.

\section{Low Masculinity}

Dominance is not welcomed and individuals are supposed to be modest and caring toward others. Standing out from the crowd is not appreciated.

Russia (36) is marked by feminism. Russians are modest and talk about their achievements and gains in a humble manner. At meetings and conversations, Russians understate their contributions, capacities and achievements. Boastful behavior is discouraged. At business meetings, managers present humble view of their own contribution and expertise.

Brazil (49) lies on the medium level. Thus the feminist aspect of culture underscores consensus and sympathy toward others. Conflicts and competition is mostly avoided at private and work life by meeting a consensus. 


\section{High UAI}

High degree of UAI shows that the society does not tolerate ambiguity and uncertainty. Unforeseen situations are avoided. Societies that feel threatened by uncertainties and ambiguity tend to elaborate detailed rules and legal systems for structured life.

Russia (95) and Brazil (76) rank very high in UAI showing structured society and rules. Individuals are expected to obey the law however weak it may be. Bureaucracy is one aspect of their society. Detailed planning and discussion is required at business meetings with the context and background of information. Russians, in contrast to Brazilians, are more formal and distant to strangers. But this distant behavior should not be mistaken for coldness or indifference. Rather, formal behavior is taken as a sign of respect. Brazilians, on the other hand, are passionate and expressive and use body language to reflect their emotions. Time for business meetings is fixed and seldom changes.

\section{Low UAI} situations.

UAI means that ambiguity is accepted and people don't feel threatened by unforeseen

US (46), China (33) and India (40) score low on this index while South Africa (49) scores high therefore it is appropriate to rank US on middle level. Consequently, new products and innovative ideas are accepted. Opinions and expressions are allowed. Americans, as an example, do not require rules to be more expressive than people from high scoring countries.

Business managers are expected to be ready for frequent rescheduling and business meetings need to be confirmed one day in advance.

\section{High LTO}

High degree of long term orientation shows that people care about their future more and hold long term point of view.

China (114), Brazil (65) and India (61) rank high on this index. Chinese society is ranked very high on this scale which is closely related to Confucius teachings of economy and perseverance.

Brazil is the only non-Asian country to rank high in this dimension. Long term perspective is underscored in assessing results and performance. Overall outcome is rewarded rather than short term results.

\section{Low LTO}

In a society with low LTO, decisions are made regarding short term point of view.

US (29) and Russia (33) rank low on this scale. This means present is given priority over future and business managers think short term. US ranks very low on this scale which reflects that the performance is measured on short-term basis and financial statements are issued quarterly basis. Quick results are expected from employees and managers.

\section{Cultural differences and Operational conflicts}

Societies high in power distance index are highly centralized leading to bureaucratic setups. This creates problems for businesses. For example, if a business plan would change many hands; it would require a number of approvals before actually reaching the table of 
the approving authority. This results in delay and often parties resort to bribery to hasten their way up on the hierarchy. Red tapism, centralization of power, lack of open communication and favoritism are some problems that may hinder the way of businesses to achieve their goals.

Also, in the collectivistic countries, the corruption problems may cause the ethical dilemma for the firm. Since, individual are expected to be loyal and faithful to their groups, there is great chance of collusions for corruption. Embezzlement of funds, fraud and falsification in business dealings may cause potential threats.

Cultural differences are at the forefront in expansion of business to international markets especially in the form of mergers and acquisitions. A firm from mature market acquiring a business in a foreign country may find itself facing huge cultural conflicts.

Researchers have found supporting evidence that national and cultural differences contribute to poor post-acquisition performance and in some cases failure of business mergers and acquisitions (Olie, 1994; Weber, 1996).

Organizational and national identities appear more salient when separate organizations are combined. Thus, the conflicts of identity-building among employees may be daunting. Since people tend to associate similarity concerning values and beliefs with trustworthiness and attractiveness, this may result in the development of in-group versus out-group biases. Such biases may amplify in the conditions of ambiguity and uncertainty about future. Consequently, people from merging organizations exhibit little understanding and even may distrust people on the other side (Terry, 2001; Vaara, 2003).

Based upon the significant research evidence the researchers suggest that in international settings, acquisitions from culturally closer nations lead to better outcomes than those from more distant cultures (Krug and Hegarty, 1997; Weber, 1996).

\section{International Organizational memberships}

Under this heading, I decided to include only those organizations in the list which are common with that for USA to make the comparison compact. If USA is a member of an organization and the potential country where the firm decides to expand the business activities is also the member of the same organizations then it would be beneficial for the firm in terms of taxes, tariffs, regulations, fair treatment etc.

\begin{tabular}{|l|l|}
\hline \multicolumn{1}{|c|}{ Country } & \multicolumn{1}{c|}{ International Organizations common with U.S.A } \\
\hline U.S.A & WTO, G 20, APEC \\
\hline Brazil & WTO, G 20 \\
\hline Russia & WTO Joined WTO on 16th December, 2011, G 20, APEC \\
\hline India & WTO, G 20 \\
\hline China & WTO, G20, APEC \\
\hline South Africa & WTO, G 20 \\
\hline
\end{tabular}

Table 2: Mutual International organizational memberships 


\section{International Organizations-Business implications}

The importance of international organizations for business and investment decisions can be summarized as follows;

Membership of international organizations such as WTO provides non-discriminatory treatment to all members. Just as WTO rules state, all foreign enterprises are accorded with the treatment no less favorable than that accorded to any other enterprise with respect to the right of trade. Thus, a firm from USA would be treated equally with a firm from any other foreign country in terms of taxes, tariffs and other aspects. This is importance on grounds of business competition and survival.

The custom duties and tariffs are reduced and enterprises operating in the country have the right to import and export throughout the customs territory with limited exceptions. WTO, for example, facilitates nondiscrimination, reciprocity, transparency and safety valves by formalizing trade framework. Also, it serves as a party for dispute resolution among trading countries.

Similarly, the membership of G20 has significant positive implications from business point of view. G20 members strive to facilitate trade and business opportunities. Recently, some G 20 countries reduced or temporarily exempted import tariffs and terminated traderestrictive actions to facilitate free trade (United Nations Conference for Trade and development, 2011). The membership of such trade organizations not only develops favorable conditions for trade but also help for expanding business operations to member countries by providing favorable treatment in terms of taxes and tariffs. For example, the membership of APEC benefits the business firms from member countries in two ways;

\section{Trade Liberalization}

Since 1989, when APEC was formed the average trade barrier has been reduced from $16.9 \%$ to $5.5 \%$ in 2004 (APEC, 2011)

\section{Business facilitation}

One of the advantages of APEC membership is that it helps in business facilitation and provides opportunities for expansion of operations to member countries with minimum costs. From 2002 to 2006 the cost of business transactions across the regions was reduced by $6 \%$ (APEC, 2011).

\begin{tabular}{|l|c|c|c|c|c|c|c|}
\hline Country & $\begin{array}{c}\text { GDP } \\
(\mathbf{p p p})\end{array}$ & $\begin{array}{c}\text { GDP } \\
\text { Growth }\end{array}$ & $\begin{array}{c}\text { GDP } \\
\text { per } \\
\text { Capital }\end{array}$ & Inflation & $\begin{array}{c}\text { Unemp- } \\
\text { loyment }\end{array}$ & $\begin{array}{c}\text { Population } \\
\text { below } \\
\text { poverty line }\end{array}$ & Main sector \\
\hline U.S.A & $\$ 14.526$ trillion & $3 \%$ & $\$ 46,860$ & $3.5 \%$ & $8.6 \%$ & $6.7 \%$ & Services $(76.6 \%)$ \\
\hline Russia & $\$ 2.23$ trillion & 4.9 & $\$ 15,807$ & 7.2 & 6.7 & 13 & Services $(59.1 \%)$ \\
\hline Brazil & $\$ 2.178$ trillion & 7.5 & $\$ 11,273$ & 6.9 & 5.7 & 15.5 & Services $(67.4 \%)$ \\
\hline South Africa & $\$ 525.8$ billion & 4.6 & $\$ 10,518$ & 4.6 & 24 & 35.7 & Services $(78.5 \%)$ \\
\hline China & $\$ 10.11$ trillion & 11.4 & $\$ 7544$ & 4.9 & 4.2 & & Industry $(46.4 \%)$ \\
\hline India & $\$ 4.05$ trillion & 8.5 & $\$ 3408$ & 9.11 & 9.4 & 37 & Services $(55.2 \%)$ \\
\hline
\end{tabular}

Table 3: Comparative economic indicators 


\section{Linder theory}

According to Linder theory, international trade between two countries occurs based upon the similar tastes and preferences, factor endowments and per capita income level. Linder postulates that countries with similar demand structure would develop similar industriesand most trade will be intra-industry trade but with differentiated goods.

\section{Application of Linder theory to international businesses}

Based upon the insight of Linder theory, it would be more advantageous for the firm from USA to export its products to a country which has similar per capita income. Looking at economic indicators of the rapidly developing countries, we find that Russia has the highest per capita income among other BRICS nations.

The products that the firm produces for American market reflect the tastes and preferences of American consumers which are influenced by their per capita income level. Overall, American society is quite prosperous with high per capita income, low unemployment, inflation and poverty level as compared to BRICS nations. The per capita income for USA is very high- $\$ 46,860$, while all the BRICS nations are far behind this level. In some emerging markets the per capita income level is quite low. For example, India \$3408 and China \$7544 are far below the USA per capita income level. Based upon the low level of income, average consumer would prefer cheaper products and brand loyalty may be quite low. Thus demand in such countries is highly price elastic (sensitive to changes in price). An average consumer would trade off brand loyalty for price differentiation. However, an average American would not be willing to compromise the brand loyalty over price differences.

\section{Implications of Linder Theory for business managers}

Practically, this seems a common observation that most of the products in Chinese and Indian markets are developed keeping the price factor in mind. Cheap products have high demand and are sold quickly. The products are meant to cater to basic needs of average consumer. Sophisticated and high quality products which are meant for the consumers at the top of the pyramid are produced at smaller scale.

If the firm expects to reach to a larger customer base with its existing products (high in quality and price), then the potential markets would be those with high per capita income like Russia, Brazil and South Africa. This is further underscored by other economic indicators which reflect the relative prosperity and consumption pattern of average consumer. Russia and Brazil have lower percentage of people below poverty line, i.e. $13 \%$ and 15.5 respectively. While, in India (37\%) and South Africa (35.7\%) a significant portion of consumers lives below poverty line earning less than $\$ 1.25$ a day. For USA, this figure is $6.7 \%$ which shows the huge difference in terms of averages tastes and consumption habits. Unemployment and high inflation are other economic factors affecting consumer preferences in low income countries.

A general tendency for American firms is to produce goods keeping the quality factor in mind. Therefore, a business manager for an American firm may use cost-plus pricing strategy for new products or markets. But a business manager from low income country may choose penetration pricing Penetration pricing means setting the price low to attract larger customer base and then gradually raise the prices with reference to demand.. Therefore, the price for which the product should be sold is given most importance. Production strategies revolve around minimizing costs and ultimate price. Quality factors are often compromised and the emphasis is given to meeting the basic needs of customers. American producers, in contrast, develop products keeping in mind the brand image and value addition in terms of sophisticated product features. 
The above discussion may lead a reader to guess that USA may run a trade deficit with low income countries. Quite remarkably, this is true. As I had also guessed, USA runs a huge trade deficit not only with China but also with India, i.e. US goods and services trade deficit was $\$ 7$ billion, according to office of United States Trade Representative, with India and $\$ 219$ billion with China in 2009. These two countries are known around the globe for cheap prices and huge variety of products catering to different levels of consumers. Cheap products with low quality are meant for low income levels, while high quality products with high prices are meant for upper strata.

\section{Recommendations}

Before actually making recommendations, I deemed it necessary to provide a brief snapshot of business favorability comparison across selected countries. Such comparison makes it easier for managers to make suitable decisions.

\begin{tabular}{|l|c|c|}
\hline Country & Ease of doing business & $\begin{array}{c}\text { Average Number of } \\
\text { Days to Start a Business }\end{array}$ \\
\hline U.S.A & 4th & 6 \\
\hline Brazil & 120 th & 119 \\
\hline Russia & 126 th & 30 \\
\hline India & 35th & 29 \\
\hline China & 91th & 38 \\
\hline South Africa & 132nd & 22 \\
\hline
\end{tabular}

Table 4: Business Favorability comparison

\section{Business strategy}

In similar cultures the business strategies can adjust quickly with a few exceptions. Since the potential market exhibits similarities in terms of market structure and cultural aspects, the firm may continue with its home-based strategy with few modifications. Thus, the US firm may adopt Global strategy and Home Replication strategies in South Africa South Africa is aligned closely with US on Hofstede's dimensions showing huge cultural similarities. Kindly refer to appendix for their amazingly similar scores may be adopted by the manager to benefit from the cultural similarities by reaping the fruits of efficiencies of scale. Both strategies maximize efficiency of scale since the level of operations and scale resembles the home market Also, in terms of ease of doing business, South Africa is the most attractive market with a score of 35 (World Bank International Finance Corporation, 2011).

However, huge cultural differences implicate that the firms needs to adjust to local responsiveness and flexibility instead of focusing on scale efficiencies. In countries like Russia, China, India and Brazil, the firm needs to adopt Trans-National or Multi-Domestic strategies to avoid cultural conflicts by focusing on local aspects of the market.

\section{Types of products and service}

As implicated by Linder theory and macroeconomic indicators, the consumer tastes and preferences differ significantly given their per capita income level. 
Therefore, while developing products for such markets the firm should keep the economic factors in mind if it expects to cater to a large chunk of consumers. Also, while exporting the existing products to such markets, the firm should adapt the product according to customers' perceptions. For example, eating at McDonalds', KFC or Pizza Hut may be a routine for an American but would be considered luxury or status symbol for people from low income countries. The firm may offer simple and need-based products to China and India (low per capita income) while sophisticated, value-based and featured products may be directed toward Russia, South Africa and Brazil (high per capita income).

\section{Modes of entry}

Mergers and acquisitions are recommended for countries with cultural and economic similarities since subsequent modifications and adjustments are easier than in countries with conflicting cultural aspects. Therefore, the firm may indulge in mergers and acquisitions or joint ventures in South Africa; it should resort to exporting, franchising or licensing for culturally and economically different markets of India, China, Russia and Brazil.

In the end, I would like to add that the firm needs to modify and adjust to potential cultural differences and need to keep such factors in mind while developing products and services for different markets.

\section{Market Characteristics create Market Opportunities}

\begin{tabular}{|c|c|}
\hline Market Characteristics & Strategy for Market Opportunities \\
\hline $\begin{array}{l}\text { Demanding Markets, } \\
\text { culture and environments }\end{array}$ & $\begin{array}{l}\text { If a bicycle is being used in the market then use a } \\
\text { bicycle instead of a bike. }\end{array}$ \\
\hline Fragmented Markets & Introduce brands that connect the market. \\
\hline $\begin{array}{l}\text { Youthful and growing } \\
\text { Population }\end{array}$ & No need to show maturity, think young. \\
\hline Limited space and income & $\begin{array}{l}\text { Think small and grow big. Don't build a plaza if a cabin } \\
\text { is enough. }\end{array}$ \\
\hline Weak Infrastructure & $\begin{array}{l}\text { Rely on your own infrastructure by developing what is } \\
\text { needed for you. }\end{array}$ \\
\hline Underdeveloped Technology & Leapfrog would be more suitable than a gallant. \\
\hline Weak Distribution channels & $\begin{array}{l}\text { Use people as your channels. Make them your market } \\
\text { rather than making market for them. }\end{array}$ \\
\hline Rapidly changing Markets & Evolve yourself with the market. \\
\hline
\end{tabular}

Table 5: Market characteristics and relevant strategies

\section{Conclusion}

I have discussed the business strategies, products and modes suitable for each market based upon cultural and economic factors. In conclusion, I would like to mention that one may wonder about the general knowledge and attitude of American managers toward 
customers. As per my discussion in Hofstede's cultural dimensions, equality prevails in all aspects of American society. Therefore, an American manager may treat the consumer preferences for quality as equal among all income levels. The underlying assumption is that the average customer prefers quality. While this is hundred percent true in terms of consumer perceptions, it is false on the grounds of reality. The consumer perceptions of how something should be (quality) are quite different from what he or she can actually afford (price). While the word "best" may be catchy for American customers, the word "cheapest" is the one most attractive for customers in China and India. This is common observation In fact, the word "cheapest" is most searched for on Google by people from low income countries. Anyone can try this by writing "cheapest" on Google and the search options provided will be for low income countries most likely to be India and Pakistan rather than high income ones

Business managers from low income countries like China and India (which rank high in Power Distance index) take into account the societal inequalities and differences while developing business strategies.

Lessons can be drawn from the distinctive and unique business strategies of Hindustan Lever and Nokia in India (Hindustan Unilever, 2011; Jain M, 2011). While both companies faced tough times in their initial period, based upon the complex demand structure and consumption pattern, they emerged successful once they were able to reach out for the average consumer. The similarity between the case studies of both companies is that both focused on delivering the consumer needs at minimal price possible. Both kept their products simple and need-based for average consumer. For example, Hindustan Unilever introduced a shampoo that worked best with cold water and sold in small packets keeping in mind the needs of poor.

Ted London from University of North Carolina, Chapel Hill, USA and Stuart L Hart from Cornell University, NY, USA are among those who argue that huge wealth lies at the base of the economic pyramid (low income strata which constitutes 4 billion consumers). They suggest that manager need to build local capacity, make non-traditional partners and use environmental obstacles as opportunities for new product offerings.

Thus, in order to succeed in the business with these countries, the local formula for price and quality should be adopted by the firm. That is, to cater to the basic need of customers in the local customized way rather than using the conventional "American Way of doing business".

\section{References}

Archdivili, 2001, Talent Development and Economic Growth in Russia, Human Resource Development Quarterly, online viewed 17th December 2011, http://www.sras.org/

Asia-Pacific Economic Cooperation, 2011, Publication Database, online viewed on 17th December 2011,http://www.apec.org/

BBC News, 2011, Debt Crisis: What Next for Europe?, viewed online 23rd December 201, time: 20.00 , http://www.bbc.co.uk/news/business-16297393

CCTV, 2011,News Channel, 16th December, 2011. 20.00

Hindustan Unilever Limited, 2011, Case Studies, online viewed on 18th December 2011,http://www.hul.co.in/sustainability/casestudies/ 
International Monetary Fund, 2011, Data and Statistics, online viewed 16th December 2011,http://www.imf.org/external/data.htm

Jain M 2010, Nokia's Business Strategy in India, online viewed on 18th December 2011 via http://www.casestudyinc.com/nokia-strategy-india

Kwintessential.com.uk, 2011, Hofstede's Cultural Dimensions, online viewed on 14th December, 2011http://www.kwintessential.co.uk/intercultural/dimensions.html

Krug, J. A. and Hegarty, W. H 1997, 'Post-acquisition turnover among U.S. top management teams: an analysis of the effects of foreign vs. domestic acquisitions of U.S. targets', Strategic Management Journal, Vol. 18, pp. 667-75, online viewed 17th December 2011, http://onlinelibrary.wiley.com/

New York Times, 2011, Russia Clears Last Hurdle for WTO Membership, online viewed 18th December 2011,http://www.nytimes.com/

Olie, R 1994, 'Shades of culture and institutions in international mergers', Organization Studies, Vol. 15, pp. 381-405, online viewed 17th December 2011, http://onlinelibrary.wiley.com/

Office of United States Trade Representative, 2011, APEC 2011 News, online viewed 17th December 2011http://www.ustr.gov/apec2011

The Telegraph, 2011, Debt crisis: as it happened December 23, 2011, accessed online 24th December 2011, Terry, D.

J 2001, 'Intergroup relations and organizational mergers', Social Identity Processes in Organizational Contexts, Philadelphia, PA: Psychology Press, 249-64, viewed $17^{\text {th }}$ December 2011, http://www.telegraph.co.uk/finance/debt-crisis-live/8974559/Debt-crisis-as-it-happenedDecember-23-2011.html://onlinelibrary.wiley.com/

United Nations Conference for Trade and Development, 2011, Main Publications, online viewed on 17th December 2011, http://www.unctad.org/en/docs/unctad_oecd2010d3_summary_en.pdf

Vaara, E 2003, 'Post-acquisition integration as sensemaking: glimpses of ambiguity, confusion, hypocrisy, and politicization', Journal of Management Studies, Vol. 40, 859-94, online viewed 17th December 2011,http://onlinelibrary.wiley.com/

Weber, Y 1996, 'Corporate cultural fit and performance in mergers and acquisitions', Human Relations, Vol. 49, 1181-202, online viewed 17th December 2011, http://onlinelibrary.wiley.com/

Wikia.com, 2011, Hofstede World Averages, online accessed on 15th December 2011 via http://internationalbusiness.wikia.com/wiki/File:Hofstede_world_average.gif

Willis Bob, 2011, Personal Spending Rises Less than Forecast, viewed online 23rd December 2011, http://www.bloomberg.com/news/2011-12-23/u-s-personal-spending-increased-lessthan-forecast-in-november.html

World Bank International Finance Corporation, 2011, Doing Business, online viewed on 15th December 2011,http://www.doingbusiness.org/rankings 
World Bank, 2011, World Development Indicators, online viewed on 15th December 2011, http://data.worldbank.org/indicator

World Bank, 2011, Development Indicators:Time required to start a business, viewed online on 14th December 2011, http://data.worldbank.org/indicator/IC.REG.DURS

Yelena Shulyatyeva, 2011, The Telegraph, accessed online, http://www.telegraph.co.uk/finance/debt-crisis-live/8972022/Debt-crisis-as-it-happenedDecember-22-2011.htm

For our human salvation, we must rid ourselves of such illusions as have made us accept immaturity. Reluctant as we may be to do so, we must acknowledge the hard fact that "to him that hath shall be given; and from him that hath not even that which he hath shall be taken away", because of the interdependence of our powers, maturity in one area of our life promotes maturity in other areas, immaturity in one area promotes immaturity in other areas. This, then, is the first basic fact about the maturity. 